\title{
Prevalence of normal electrocardiograms in primary care patients
}

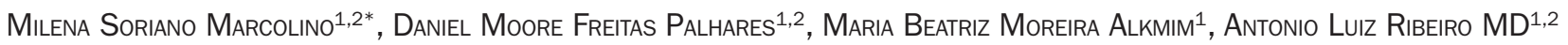 \\ ${ }^{1}$ Telehealth Network of Minas Gerais, Hospital das Clínicas, Federal University of Minas Gerais, Belo Horizonte, MG, Brazil \\ ${ }^{2}$ Department of Clinical Practice, Faculty of Medicine, Federal University of Minas Gerais, Belo Horizonte, MG, Brazi
}

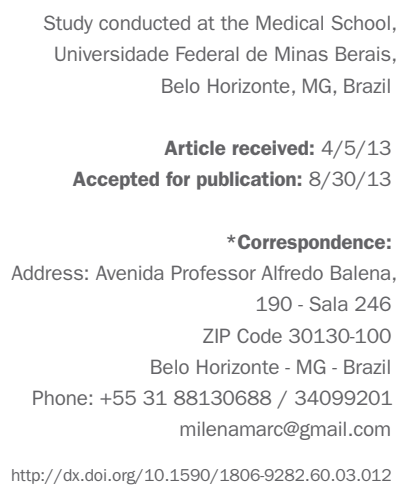

Study conducted at the Medical School Universidade Federal de Minas Berais,

Belo Horizonte, MG, Brazil

Article received: $4 / 5 / 13$

Accepted for publication: $8 / 30 / 13$

*Correspondence:

Address: Avenida Professor Alfredo Balena, 190 - Sala 246

ZIP Code 30130-100

Belo Horizonte - MG - Brazil

Phone: +55 3188130688 / 34099201

milenamarc@gmail.com

http://dx.doi.org/10.1590/1806-9282.60.03.012

Conflict of interest: none

\section{SUMmARY}

Objective: Knowing the proportion the proportion of normal and abnormal electrocardiograms (ECGs) in primary care patients allows us to estimate the proportion of exams that can be analyzed by the general practitioner with minimal training in ECG interpretation, in addition to being epidemiologically relevant. The objective of this study is to assess the prevalence of normal ECGs in primary care patients.

Methods: all digital ECGs analyzed by the cardiologists of Telehealth Network of Minas Gerais (TNMG) in 2011 were evaluated. TNMG is a public telehealth service that provides support to primary care professionals in 662 municipalities in the state of Minas Gerais, Brazil.

Results: during the study period, 290,795 ECGs were analyzed (mean age $51 \pm$ 19 years), $57.6 \%$ were normal. This proportion was higher in women (60.1 vs 57.6\%, $\mathrm{p}<0.001)$ and lower in patients with hypertension $(45.8 \%$ vs $63.2 \%, \mathrm{p}<0.001)$ or diabetes $(43.3 \%$ vs $63.2 \%, \mathrm{p}<0.001)$. A progressive reduction in the prevalence of normal ECG with increasing age was observed. Among the ECGs of patients under investigation for chest pain, $58.7 \%$ showed no abnormalities.

Conclusion: the prevalence of normal ECGs in primary care patients is higher than $50 \%$ and this proportion decreases with age and comorbidities. Most ECGs performed for investigation of chest pain in primary care shows no abnormality.

Uniterms: electrocardiography, telemedicine, primary health care.

\section{INTRODUCTION}

The electrocardiogram (ECG) is a method of investigation of the cardiovascular system with established prognostic and diagnostic value, easy to perform, has low cost and great clinical utility. ${ }^{1}$

The progressive development of electrocardiographic recording and transmission equipment, incorporating miniaturized and resistant electronic circuits, has led to the development of digital ECG that once connected to the internet, enables the transmission of the signal in real time for remote analysis. ${ }^{2}$

The Telehealth Network of Minas Gerais (TNMG) is a public telemedicine service that serves more than 850 primary care units in 662 municipalities in Minas Gerais, Brazil, covering $47.2 \%$ of the state population, approxima- tely 9,265,820 inhabitants. The Network offers tele-electrocardiography and teleconsultation services. The tele-electrocardiography service provides support for primary care physicians through the transmission of digital ECG and case discussion in real time with cardiologists. There are benefits such as reducing the number of referrals and identifying patients who need urgent care. ${ }^{1,3,4}$

This service is fully integrated into the health system of all municipalities and is very successful, having performed over 1,700,000 ECG reports, which currently corresponds to an average of 1,700 exams per day. Given the large number of tests performed, the analysis of ECGs can allow the knowledge of the proportion of normal and abnormal ECGs in primary care patients. In addition to 
having great epidemiological relevance, these data allow us to estimate the proportion of patients with ECGs that could be analyzed by general practitioners with minimal training in ECG interpretation, and also help estimate the percentage of patients who require further investigation.

Thus, the aim of this study is to evaluate the prevalence of ECGs without abnormalities in primary care patients in Minas Gerais, Brazil, considering the tests analyzed by cardiologists of the tele-electrocardiography service.

\section{Methods}

ECGs are performed in the places of origin and transmitted by remote teams over the Internet to the RTMG analysis center. In the analysis center, the exams are immediately directed the team of cardiologists, who are professionals trained and experienced in ECG analysis and interpretation. These professionals issue a report, using standardized criteria, ${ }^{5}$ which is accessed at the source. Measures to ensure the quality of the service include periodic discussion of diagnostic criteria and periodic audits in the ECG reports.

This observational and retrospective study included all examinations using digital 12-lead electrocardiogram analyzed by cardiologists of the TNMG in 2011. The prevalence of normal ECGs was evaluated.

Statistical analysis was performed using SPSS software (SPSS Inc., Chicago, IL) version 18.0. Categorical variables were expressed as counts and percentages, and chi-square test was used to compare the prevalence of ECG without change according to comorbidities. A p value of 0.05 was considered statistically significant, and all $\mathrm{p}$ values are two-tailed.

This study was approved by the Ethics and Research Committee of the Federal University of Minas Gerais, with issuance of opinion ETIC 0072.0.203.00-11.

\section{Results}

During the study period, a total of 290,799 ECGs were evaluated, and 273,070 (93.9\%) were performed in primary care units in the countryside of Minas Gerais and 17,729 in primary care units of the state capital, Belo Horizonte (6.1\%). The mean age was $51 \pm 19$ years, ranging from 1 to 105 years; $59.3 \%$ were women. The clinical characteristics of these patients are summarized in Table 1. Hypertension was the most common comorbidity.

Regarding the tests requested in the countryside, the median of the population of the municipalities that requested analyses of tests was 8,924 inhabitants (interquartile range 5.225 to 14.592 ). Tables $2-4$ summarize demographic information from requesting municipalities. It should be noted that most of ECGs were originated from municipalities with fewer than 10,000 inhabitants. Regarding the 10 municipalities that requested the highest number of ECGs (7.6\% of the total), all of them are located more than 250 kilometers from the capital, 9 have HDI bellow the state average and GDP per capita less than half of the state average. In addittion, they have a higher proportion of poor and extremely poor people and a higher rate of illiteracy compared to the state average. Eight of them are situated in the northern region of Minas Gerais, in the mesoregion where nearly a quarter of exams were originated from.

\begin{tabular}{l} 
TABLE 1 Clinical characteristics of primary care \\
patients who underwent electrocardiography using the \\
service of the Telehealth Network of Minas Gerais in \\
$\begin{array}{l}2011(\mathrm{~N}=290,799) \\
\text { Clinical characteristics }\end{array}$ \\
\hline Hypertension
\end{tabular}

\section{TABLE 2 Number of electrocardiograms requested} according to population group of municipalities

\begin{tabular}{|c|c|c|c|}
\hline Population range* & $\begin{array}{l}\text { ECGs } \\
\text { requested } \\
\mathrm{N}(\%)\end{array}$ & $\begin{array}{l}\mathrm{N} \text { total } \\
\text { municipalities } \\
\text { in the state }\end{array}$ & $\begin{array}{l}\text { Municipalities } \\
\text { assisted by the } \\
\text { TNMG } \\
\text { N (\%)** }\end{array}$ \\
\hline 0 to 3,500 & $22334(8.18)$ & 108 & $107(16.2)$ \\
\hline 3,501 to 7,000 & $\begin{array}{l}83256 \\
(30.49)\end{array}$ & 275 & $266(40.2)$ \\
\hline 7,001 to 14,000 & $\begin{array}{l}94271 \\
(34.52)\end{array}$ & 208 & $188(28.4)$ \\
\hline 14,001 to 28,000 & $\begin{array}{l}40909 \\
(14.98)\end{array}$ & 146 & $64(9.7)$ \\
\hline 28,001 to 42,000 & $19694(7.21)$ & 40 & $20(3.0)$ \\
\hline 42,001 to 98,000 & $12513(4.58)$ & 47 & $14(2.1)$ \\
\hline $\begin{array}{l}98,001 \text { to } \\
266,000\end{array}$ & $87(0.03)$ & 20 & $2(0.3)$ \\
\hline $\begin{array}{l}266,001 \text { to } \\
532,000\end{array}$ & $6(0.00)$ & 6 & $1(0.01)$ \\
\hline$>532$ thousand & - & 3 & $0(0.01)$ \\
\hline Total & $273070 * * *$ & 853 & 662 \\
\hline
\end{tabular}

TNMG: Telehealth Network of Minas Gerais

* Brazilian Census Bureau, IBGE/2010

** Percentage of total municipalities assisted by the TNMC

*** This does not include the Basic Health Units in Belo Horizonte 
TABLE 3 Characteristics of the ten municipalities that requested the highest number of electrocardiograms * from January to December 2011 compared to Belo Horizonte, Minas Gerais and Brazil

\begin{tabular}{|c|c|c|c|c|c|c|c|c|c|}
\hline Municipality & $\begin{array}{l}\text { Population } \\
\text { (IBGE/2010) }\end{array}$ & $\begin{array}{l}\text { ECGs } \\
\mathrm{N}(\% \text { of } 2011 \text { 's } \\
\text { total) }\end{array}$ & $\begin{array}{l}\text { Distance } \\
\text { from the } \\
\text { capital }\end{array}$ & $\begin{array}{l}\text { MHDI } \\
(\text { UNDP } \\
(2010)^{* *}\end{array}$ & $\begin{array}{l}\text { GDP per } \\
\text { capita }\end{array}$ & Mesoregion & $\begin{array}{l}\% \text { of poor } \\
\text { people }{ }^{* * *}\end{array}$ & $\begin{array}{l}\% \text { of extremely } \\
\text { poor } \\
\text { people }{ }^{* * * *}\end{array}$ & $\begin{array}{l}\text { Illiteracy rate } \\
* * * * *\end{array}$ \\
\hline $\begin{array}{l}\text { São } \\
\text { Francisco }\end{array}$ & 53,828 & $3,686(1.3 \%)$ & $658 \mathrm{~km}$ & 0.638 & 4880.25 & $\begin{array}{l}\text { Northern } \\
\text { Minas }\end{array}$ & 37.96 & 15.88 & 23.67 \\
\hline Pirapora & 53,368 & $2,526(0.9 \%)$ & $340 \mathrm{~km}$ & 0.731 & 19756.77 & $\begin{array}{l}\text { Northern } \\
\text { Minas }\end{array}$ & 13.06 & 2.91 & 8.99 \\
\hline Mirabela & 13,042 & $2,274(0.8 \%)$ & $483 \mathrm{~km}$ & 0.665 & 4822.54 & $\begin{array}{l}\text { Northern } \\
\text { Minas }\end{array}$ & 29.25 & 10.93 & 22.35 \\
\hline Bocaiúva & 46,654 & $2,259(0.8 \%)$ & 369 km & 0.700 & 8807.16 & $\begin{array}{l}\text { Northern } \\
\text { Minas }\end{array}$ & 20.13 & 6.24 & 16.38 \\
\hline Turmalina & 18,055 & $2,073(0.8 \%)$ & 480 km & 0.682 & 7059.94 & Jequitinhonha & 19.79 & 7.76 & 19.84 \\
\hline Espinosa & 31,113 & $2,038(0.7 \%)$ & $699 \mathrm{~km}$ & 0.627 & 5006.30 & $\begin{array}{l}\text { Northern } \\
\text { Minas }\end{array}$ & 29.03 & 12.73 & 30.81 \\
\hline Porteirinha & 37,627 & $1,871(0.7 \%)$ & 591 km & 0.651 & 4679.57 & $\begin{array}{l}\text { Northern } \\
\text { Minas }\end{array}$ & 32.00 & 14.33 & 27.40 \\
\hline Janaúba & 66,803 & $1,850(0.7 \%)$ & $540 \mathrm{~km}$ & 0.696 & 7854.37 & $\begin{array}{l}\text { Northern } \\
\text { Minas }\end{array}$ & 18.98 & 4.07 & 18.75 \\
\hline Buenópolis & 10,291 & $1,813(0.7 \%)$ & $272 \mathrm{~km}$ & 0.669 & 7333.30 & Central Minas & 20.62 & 7.80 & 19.80 \\
\hline Varzelândia & 19,116 & $1,709(0.6 \%)$ & $590 \mathrm{~km}$ & 0.594 & 4631.76 & $\begin{array}{l}\text { Northern } \\
\text { Minas }\end{array}$ & 43.84 & 22.81 & 33.46 \\
\hline $\begin{array}{l}\text { Belo } \\
\text { Horizonte }\end{array}$ & $2,375,151$ & -- & -- & 0.810 & 21748.25 & -- & 3.80 & 0.79 & 3.45 \\
\hline $\begin{array}{l}\text { Minas } \\
\text { Gerais }\end{array}$ & $19,383,604$ & -- & -- & 0.731 & 17931.89 & -- & 10.97 & 3.49 & 10.36 \\
\hline Brazil & $190,755,799$ & -- & -- & 0.727 & 19766.33 & -- & 15.2 & 6.62 & 11.82 \\
\hline
\end{tabular}

* This table does not include the primary care units in Belo Horizonte

** Municipal Human Development Index. Geometric mean of indexes for income, education and longevity dimensions with equal weights.

*** Proportion of individuals with per capita household income equal to or less than BRL 140.00 monthly, in August 2010. The universe of individuals is limited to those living in permanent private households.

**** Proportion of individuals with per capita household income equal to or less than BRL 70.00 monthly, in August 2010. The universe of individuals is limited to those living in permanent private households.

***** Ratio of the population aged 25 or older who cannot read or write a simple note and the total of people in this age group multiplied by 100.

Regarding the reason for requesting the ECG, a sample of examinations conducted in January 2011 was evaluated: among the 19,370 examinations, 13,679 were performed to investigate chest pain (70.6\%) and in 4298 examinations (22.2\%) the reason was not explained. Among the remaining 1483 (7.2\%), the most common reasons reported by the applicant were periodic health assessment (38.8\%), preoperative evaluation (19.5\%), clinical evaluation (15.9\%), evaluation of a patient complaining of palpitations $(6.2 \%)$, monitoring of patients with Chagas disease $(3.8 \%)$, evaluation and monitoring of patients using $\mathrm{N}$-methylglucamine antimoniate (3.8\%).
Among the exams evaluated, 57.6\% had no abnormalities. This proportion was higher in women $(60.1 \% v$ s. $53.8 \%, \mathrm{p}<0.001)$. Progressive reduction in the prevalence of normal examinations was seen with increasing age (Figure 1), as well as significant negative correlation between age and the proportion of normal ECGs (Spearman correlation coefficient $-0.33, \mathrm{p}<0.001$ ).

In addittion, the prevalence of normal ECGs was lower in patients with hypertension $(45.8 \% v$ s. $63.2 \%$, $\mathrm{p}<0,001)$ and diabetes $(43.3 \%$ vs. $58.4 \%, \mathrm{p}<0.001)$. As expected, the prevalence was also lower in patients with a history of previous myocardial infarction $(31.1 \%)$ and 


\section{TABLE 4 Number of electrocardiograms requested according to mesoregions in Minas Gerais}

\begin{tabular}{|c|c|c|c|c|c|c|}
\hline Mesoregion & $\begin{array}{l}\text { Total ECGs } \\
\mathrm{N}(\%)\end{array}$ & $\begin{array}{l}\mathrm{N} \text { total } \\
\text { municipalities } \\
\text { in the state }\end{array}$ & $\begin{array}{l}\text { Municipalities in } \\
\text { the TNMG N (\% } \\
\text { of the state's } \\
\text { total) }\end{array}$ & $\begin{array}{l}\text { GDP per } \\
\text { capita** }\end{array}$ & $\mathrm{HDI}^{* *}$ & $\begin{array}{l}\text { Normal } \\
\text { ECGs }\end{array}$ \\
\hline Northern Minas & $64.693(23.7)$ & 86 & $86(100)$ & 6634.27 & 0.647 & 56.7 \\
\hline $\begin{array}{l}\text { Belo Horizonte's } \\
\text { metropolitan area* }\end{array}$ & $29.411(10.8)$ & 103 & $65(63.1)$ & 18364.98 & 0.676 & 55.5 \\
\hline Zona da Mata & $27.791(10.2)$ & 94 & $84(89.4)$ & 9382.50 & 0.672 & 59.5 \\
\hline Southern / Southwestern Minas & $24.582(9)$ & 153 & $96(62.7)$ & 13900.36 & 0.685 & 59.3 \\
\hline Vale do Mucuri & $23.409(8.6)$ & 63 & $62(98.4)$ & 6042.47 & 0.633 & 58.9 \\
\hline Campo das Vertentes & $20.555(7.5)$ & 51 & $45(88.2)$ & 10907.72 & 0.667 & 57.0 \\
\hline Vale do Rio Doce & $19.073(7)$ & 85 & $68(80)$ & 7592.37 & 0.652 & 61.5 \\
\hline Central Mineira & $15.316(5.6)$ & 52 & $43(82.7)$ & 8088.59 & 0.647 & 59.4 \\
\hline Jequitinhonha & $14.886(5.5)$ & 23 & $23(100)$ & 5956.93 & 0.648 & 55.4 \\
\hline Western Minas & $11.220(4.1)$ & 56 & $41(73.2)$ & 14283.41 & 0.691 & 59.2 \\
\hline Northwest & $7.324(2.7)$ & 33 & $22(66.7)$ & 15077.62 & 0.671 & 55.0 \\
\hline Triângulo Mineiro and Alto Paranaíba & $14.810(5.4)$ & 54 & $27(50)$ & 27965.75 & 0.698 & 56.0 \\
\hline Total & 273070 & & & & & \\
\hline
\end{tabular}

* This figure does not include the primary care units in Belo Horizonte

ECGs: electrocardiograms

** Arithmetic mean of the GDP per capita. and MHDI of the municipalities in each mesoregion

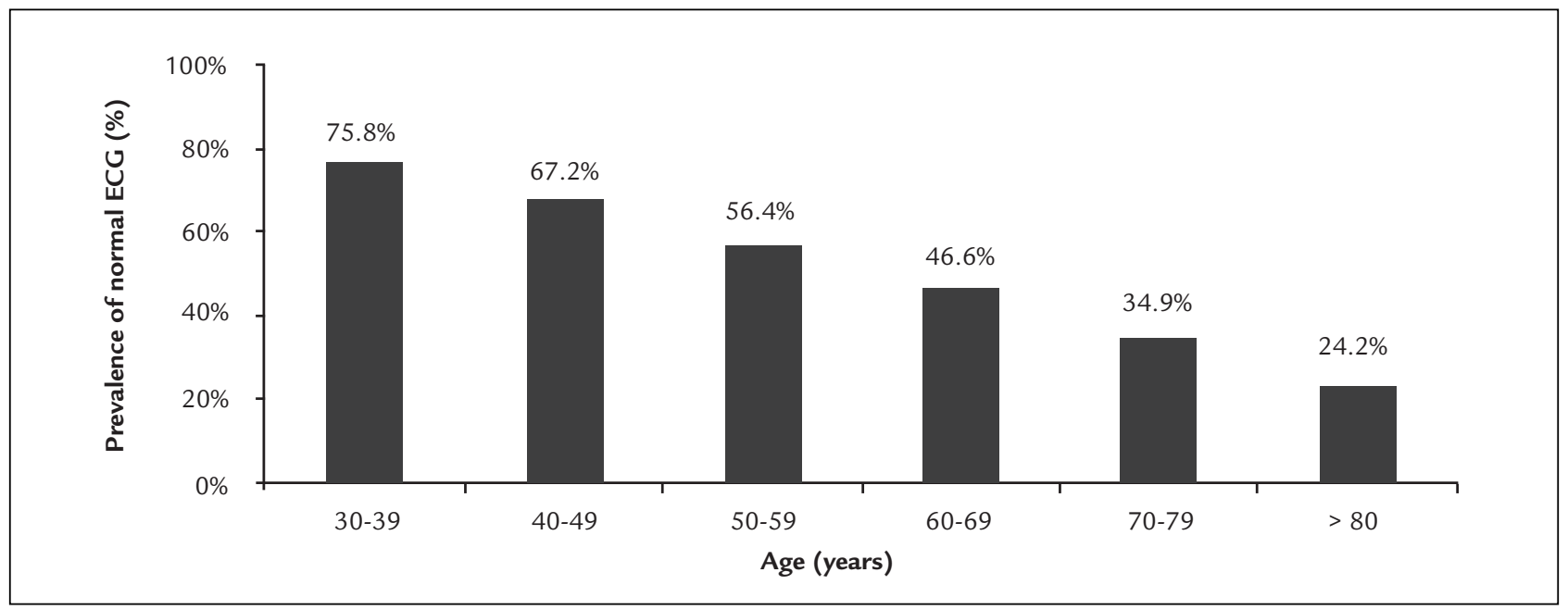

FIGURE 1 Prevalence of normal electrocardiograms according to age group. 
Chagas disease (28.5\%), which is still an endemic disease in South American countries. ${ }^{6}$

Furthermore, a variation of the proportion of normal ECGs was observed, ranging from 55.0 to $61.5 \%$, depending on the mesoregion where the exam originated from. (Table 4).

Regarding the ECGs requested to investigate chest pain, $(n=218,081)$, the mean age of patients was $51 \pm 19$ years, $59.1 \%$ were women. No abnormality was observed in $58.7 \%$ of the exams.

\section{Discussion}

This is the first study to assess the prevalence of normal ECGs exclusively in primary care patients. It was based on the analysis of a large database of a telehealth service fully integrated to the cities' primary care service and found that, in this group of patients, over $50 \%$ of all exams have no abnormality. This finding is very important because it suggests that general practitioners with minimal training in ECG interpretation can analyze most ECGs of primary care patients, especially patients without comorbidities.

Giuliano et al. assessed the prevalence of electrocardiographic abnormalities in a telemedicine service database from the State of Santa Catarina and observed a prevalence of normal ECGs significantly lower than in the present study (47.2\% vs. $57.6 \%),{ }^{7}$ because there was no restriction of evaluation for primary care patients $(72.0 \%$ primary, $22.0 \%$ secondary and $6.0 \%$ tertiary), ${ }^{7}$ which would explain the higher prevalence of abnormal results.

Furthermore, this study shows the importance of a telecardiology service for the recognition of important conditions to health policies. The recognition of the importance of chronic diseases on morbidity and mortality in Brazil prompted the Ministry of Health (MH) to create, in 2011, the "Plano de Ações Estratégicas para o Enfrentamento das Doenças Crônicas Não Transmissiveis", an action plan to reduce the impact of chronic non-communicable diseases, in which the patient's integral care is a mainstay. ${ }^{10,11}$ To meet this guideline, the MH created "Rede de Atenção às Pessoas com Doenças Crônicas", a system of care for people with chronic diseases, establishing primary care as an ordering instance of the network and care coordinator. The system of care's need to count on proper diagnostic support and use the telehealth systems as qualification tools for management is also recognized. ${ }^{12}$
Therefore, when the telemedicine service is integrated into the health system, as in this case, the results of analysis of digital ECG may have an important role in planning public health, and knowing the proportion of normal results can guide training strategies in electrocardiography. The ideal strategy would be the training of primary care physicians for recognizing normal ECGs, as well as the most common abnormal electrocardiographic patterns, using remote analysis in cases of more complex traces.

Despite the fact that complaints of chest pain are common in primary care, acute coronary syndrome is a rare cause of chest pain in this population..$^{8,9}$ In the present study, $58.7 \%$ of the ECGs of patients being investigated for the cause of chest pain showed no abnormalities. In this case, physicians should be aware of the possibility of acute coronary syndrome with normal ECG, and the importance of careful assessment of clinical symptoms as well as performing serial ECGs in suspected cases.

This study has certain limitations. Only the prevalence of normal ECGs was evaluated without specifically assessing the frequency of specific abnormalities, which will be the subject of further studies. The electrocardiographic reports followed predetermined standards, using criteria defined by the Brazilian Society of Cardiology. These criteria have not been validated in prospective population studies, such as the Minnesota code (13). Intra- and interobserver variability were not studied either. Nevertheless, the criteria used reflect the current practice in the country, ensuring the possibility of generalizing the results to other primary health care settings in Brazil.

\section{Conclusion}

This study showed that in primary care patients, normal ECGs represent over $50 \%$ of all the exams. This prevalence decreases with age and comorbidities. Furthermore, it was observed that most ECGs performed to investigate chest pain in primary care setting showed no abnormalities.

\section{Financing}

This study received no specific funding. The Telehealth Network of Minas Gerais receives funding from the Ministry of Health and the State Department of Health of Minas Gerais. ALR receives grants from the National Council for Scientific and Technological Development $(\mathrm{CNPq})$ and the Minas Gerais State Research Foundation (FAPEMIG). 


\section{Resumo}

Prevalência de eletrocardiogramas normais em pacientes da atenção primária

Objetivo: o conhecimento da proporção de eletrocardiogramas (ECG) normais e alterados em pacientes atendidos na atenção primária permite estimar a proporção de exames que pode ser analisada pelo médico generalista com formação mínima na interpretação do ECG, além de ter relevância epidemiológica. O objetivo deste estudo é avaliar a prevalência de ECG sem alterações em pacientes atendidos na Atenção Primária.

Métodos: todos os ECG digitais analisados pelos cardiologistas da Rede de Teleassistência de Minas Gerais (RTMG) no ano de 2011 foram avaliados. A RTMG é um serviço público de telessaúde, que atende a atenção primária em 662 municípios em Minas Gerais, Brasil.

Resultados: no período do estudo, 290.795 ECG foram analisados (idade média $51 \pm 19$ anos) e 57,6\% deles eram normais. Essa proporção foi maior em mulheres $(60,1 \mathrm{vs}$. $57,6 \%, \mathrm{p}<0,001)$ e menor em pacientes com hipertensão $(45,8 \%$ vs. $63,2 \%, \mathrm{p}<0,001)$ ou diabetes $(43,3 \%$ vs. $63,2 \%$, $\mathrm{p}<0,001)$. Foi observada redução progressiva na prevalência de ECG normal com o aumento da idade. Entre os ECG de pacientes em investigação para dor torácica, 58,7\% não apresentaram alterações.

Conclusão: a prevalência de ECG normais em pacientes da atenção primária é superior a 50\% e essa proporção diminui com a idade e a presença de comorbidades. A maioria dos ECG realizados para investigação de dor torácica na atenção primária não tem alterações.

Unitermos: eletrocardiografia; telemedicina; atenção primária à saúde.

\section{References}

1. Ribeiro AL, Alkmim MB, Cardoso CS, Carvalho GG, Caiaffa WT, Andrade MV, et al. Implantação de um sistema de telecardiologia em Minas Gerais: Projeto Minas Telecardio. Arq Bras Cardiol. 2010;95(1):70-8.

2. Hjelm NM, Julius HW. Centenary of tele-electrocardiography and telephonocardiography. J Telemed Telecare. 2005;11(7):336-8.

3. Andrade MV, Maia AC, Cardoso CS, Alkmim MB, Ribeiro AL. Custo-benefício do serviço de telecardiologia no Estado de Minas Gerais: projeto Minas Telecardio. Arq Bras Cardiol. 2011;97(4):307-16.

4. Alkmim MB, Figueira RM, Marcolino MS, Cardoso CS, Pena de Abreu M, Cunha LR, et al. Improving patient access to specialized health care: the Telehealth Network of Minas Gerais, Brazil. Bull World Health Org. 2012;90(5):373-8

5. Sociedade Brasileira de Cardiologia. Diretrizes da Sociedade Brasileira de Cardiologia sobre Ánalise e Emissão de Laudos Eletrocardiográficos. Arq Bras Cardiol. 2009;93(3 Suppl 2):2-19.

6. Ribeiro AL, Nunes MP, Teixeira MM, Rocha MO. Diagnosis and management of Chagas disease and cardiomyopathy. Nat Rev Cardiol. 2012;9(10):576-89.

7. Giuliano ID, Barcellos Junior CL, von Wangenheim A, Coutinho MS. Emissão de laudos eletrocardiográficos a distância: experiência da rede catarinense de telemedicina. Arq Bras Cardiol. 2012;99(5):1023-30.

8. Ebell MH. Evaluation of chest pain in primary care patients. Am Fam Physician. 2011;83(5):603-5.

9. França FAC, Lima DL, Tukamoto KB, de França LA, Neto CMC, Coan L, et al. Infarto agudo do miocárdio com supradesnivelamento de ST ao nível ambulatorial na rede de saúde públlica do Estado de São Paulo através da tele-eletrocardiografia S. Arq Bras Cardiol. 2010;95(3 Supl 1):113.

10. Brasil. Ministério da Saúde. Programa Nacional de Doenças Crônicas, 2011. [citado 15 ago 2013]. Disponível em: http://dab.saude.gov.br/portaldab/ doencas_cronicas.php.

11. Brasil. Ministério da Saúde. Secretaria de Vigilância em Saúde. Departamento de Análise de Situação de Saúde. Plano de ações estratégicas para o enfrentamento das doenças crônicas não transmissíveis (DCNT) no Brasil 2011-2022 / Ministério da Saúde. Secretaria de Vigilância em Saúde.

12. Departamento de Análise de Situação de Saúde. [citado 15 ago 2013] Brasília(DF): Ministério da Saúde; 2011. (Série B. Textos básicos de saúde). Disponível em: http://portal.saude.gov.br/portal/arquivos/pdf/cartilha_dent_ pequena_portugues_espanhol.pdf.

13. Brasil. Ministério da Saúde. Secretaria de Atenção à Saúde. Departamento de Atenção Básica. Documento de diretrizes para o cuidado das pessoas com doenças crônicas nas Redes de Atenção à Saúde e nas linhas de cuidado prioritárias / Ministério da Saúde. Secretaria de Atenção à Saúde. Departamento de Atenção Básica. [citado 15 ago 2013]. Brasília (DF): Ministério da Saúde; 2012. (Série B. Textos Básicos de Saúde). Disponível em: http://189.28.128.100/ dab/docs/portaldab/documentos/documento_norteador_cronicas.pdf.

14. Prineas RJ, Crow RS, Blackburn H. The Minnesota Code Manual of Electrocardiographic Findings. Littleton: John Wright-PSG; 1982. 